\title{
CHALLENGES OF IMPLEMENTING SOCIAL MEDIA INFORMATION SYSTEMS IN UNIVERSITIES: A REGIONAL STUDY
}

\author{
Constanta Nicoleta Bodea, Bucharest University of Economic Studies, bodea@ase.ro \\ Maria Iuliana Dascalu, University Politehnica of Bucharest, maria.dascalu@upb.ro \\ Martina Huemann, Vienna University of Economics and Business, martina.huemann@wu.ac.at \\ Gordana Velikic, RT-RK, Novi Sad, gordana.velikic@rt-rk.com \\ Radu Ioan Mogos, Bucharest University of Economic Studies, mogos.radu@gmail.com
}

\begin{abstract}
The concept of Education 3.0 has emerged from the technology-enhanced learning domain, as a results of several factors, such as: the technological progress of social media, big data and cloud technologies, virtual reality, sensory technologies; the increased importance given to education and to the new forms of education (continuous, competences oriented, collaborative/ social, online); the widespread use of so-called Massive Open Online Courses (MOOCs) or Learning Management Systems (LMS), such as: Moodle, Blackboard, Sakai.

The paper presents the analysis of the main challenges of adopting social media information systems (SMISs) in universities, by applying the Rogers's innovation diffusion model on data collected in two online surveys carried out in the framework of the START-SoPI project. The project has aimed to determine the feasibility of pan-European social media platforms for lifelong learning programs delivered by the universities in the European region of Danube River.

Based upon the results of our study, we conclude that significant challenges exist in adopting and implementing SMISs in universities, which are mainly related to the stakeholders' perceptions and motivations and to the organizational culture.
\end{abstract}

Keywords: Social media information systems, technology-enhanced learning, social networks, professional ecommunities.

\section{INTRODUCTION}

The social media information systems (SMISs) represent innovative information systems, which support the content sharing among networks of users (Kroenke, 2017). In education, SMISs assures the social support, as an additional new feature of the traditional information systems. According to House (1981), there are four categories of social support which can be provided by social networks: emotional, instrumental, informational and appraisal (feedback and affirmation) support. There are pros and cons regarding the use of social networks in e-learning activities: as strong points - it is accessible to everyone, it is affordable, it boosts collaboration and active learning, it enhances learner engagement; as cons - it is distracting, it is not as secure as a learning management system, it limits the control one may have over the learning content, it cannot provide feedback on performance (Pappas, 2015). SMISs connect the universities learning environment with social networks, in order to provide to the students the opportunity to find suitable professional e-communities, in which they can share and gain knowledge. Their professional visibility is enhanced, as exceptional behaviour within the communities is rewarded by recommending them to job recruiters who seek competent workers.

Connecting the learning environment of the university with social networks requires defining and implementing innovative IT solutions in education. In our days, there is a growing interest to understand and enhance the diffusion of innovations in education, mainly due to the spread of technology-enhanced learning. Oldenburg and Glanz (2008) and Greenhalgh et al (2005) developed important research synthesis on this topic. The research approaches (Rogers, 2003; Wejnert, 2002) use different conceptual frameworks, which focus on the innovation determinants/factors, the stages of innovation process, or the organizational context and culture. 
In order to explain the diffusion of innovations, Rogers (2003) defined three groups of variables: (1) the innovation characteristics, (2) the adopters' characteristics, and (3) contextual settings.

(1) The characteristics of innovations which are most likely to affect the diffusion process are the following: the relative advantage (innovation is better than what was there before), compatibility (the innovation fits with the intended audience), complexity (the innovation is easy to use), trialability (the innovation can be tried before to decide the innovation adoption) and observability (the results of the innovation are visible and easily measurable)

(2) Characteristics of individuals. Rogers (2003) defined five adopter categories: (1) innovators, (2) early adopters, (3) early majority adopters, (4) late majority adopters, and (5) laggards. Even if the initial aim of these categories was to allow the planning of innovation interventions, the adopter categories often were used as explanatory or predictor variables. These individual characteristics include psychological factors (for example, learning style, tolerance to ambiguity), attitudes, intentions and concerns.

(3) Contextual settings. Many different features of settings can influence the diffusion process, such as: the geographical settings, organization culture, social and political factors (Wejnert, 2002).

\section{RESEARCH METHODOLOGY}

The challenges of implementing SMIS in universities were identified by applying the innovation diffusing model of Rogers on data collected in a joint education project, entitled "Feasibility Study on Implementing a Pan-European Social Platform to Support Lifelong Learning and Employability", and having the acronym START-SoPI (START -

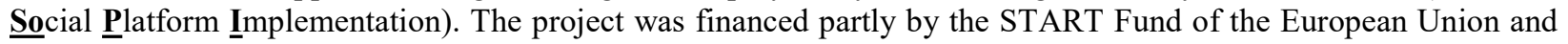
of City of Vienna and partly by the project partners (http://startsopi.ase.ro/). The project objective was to conduct a regional study on Danube countries in order to check the feasibility of developing and deploying a pan-European social platform in the Danube region. The Danube region includes 14 European countries: Austria, Bosnia and Herzegovina, Bulgaria, Croatia, Czech Republic, Hungary, Germany, Moldova, Montenegro, Romania, Slovakia, Slovenia, Serbia and Ukraine. This region is an important area of the European Union, as it covers a fifth of the EU's surface and it includes over 100 million inhabitants. Even if these countries have different educational systems, most of them are facing with similar educational challenges, such as: school dropout or low academic performance and limited students' employability.

The START-SoPI project ascertained the feasibility of an innovative solution for connecting the universities' learning environments with social networks in order to provide the opportunity to the students to find suitable professional e-communities, in which they can share and gain knowledge. Their professional visibility is enhanced, as the excellent behaviours are rewarded within these communities, by recommending them to job recruiters who seek competent workers. Along with careers services, campus job fairs and workshops, internships and mentoring of students, the social e-learning platforms can improve the collaboration between higher education institutions and employers.

The project was implemented in 2015-2016. There were project partners, from three countries of the Danube Region: Romania, Serbia and Austria. Various stakeholders were identified before performing the stages previous described: students (graduates), professors, companies, recruiters, educational institutions/ universities, existent ecommunities, public administration and so on. Only four of them were considered for analysis, as the interaction with them will provide us enough input to establish the feasibility of the platform: students, professors, companies (here we included personnel from management, HR or operational), educational institutions/ universities (here we chose personnel from the career development center or related).

Two online surveys were organized in the project: one for students and one for professors. In total, 391 questionnaires of students and 59 questionnaires of professors from various countries were validated. In addition to the online surveys, 21 structured interviews with companies' representatives, students, professors and personnel from career development centers were performed in three countries (Romania, Serbia and Austria). Also, a focus group was organized in Serbia in order to identify alternative solutions for the learning social platform. 
The characteristics of the sample population are shown in Tables 1 and 2.

Table 1. The students' characteristics

\begin{tabular}{|c|c|c|c|}
\hline \multirow[t]{2}{*}{ Students' characteristic } & \multicolumn{2}{|c|}{ Gender } & \multirow[t]{2}{*}{ Total } \\
\hline & Female & Male & \\
\hline \multicolumn{4}{|l|}{\begin{tabular}{|l|} 
The level of study: \\
\end{tabular}} \\
\hline bachelor & 81 & 133 & 214 \\
\hline graduated bachelor & 6 & 12 & 18 \\
\hline graduated master & 3 & 25 & 28 \\
\hline master & 36 & 80 & 116 \\
\hline PhD student & 3 & 12 & 15 \\
\hline \multicolumn{4}{|l|}{ Active involvement in social networks: } \\
\hline No & 11 & 61 & 72 \\
\hline Yes & 118 & 201 & 319 \\
\hline \multicolumn{4}{|l|}{ Member of professional e-Communities: } \\
\hline No & 96 & 191 & 287 \\
\hline Yes & 33 & 71 & 104 \\
\hline \multicolumn{4}{|c|}{ Usage of learning management system (LMS) in class: } \\
\hline No & 95 & 200 & 295 \\
\hline Yes & 34 & 62 & 96 \\
\hline TOTAL & 129 & 262 & 391 \\
\hline
\end{tabular}

Table 2. The professors' characteristics

\begin{tabular}{|c|c|c|c|c|c|c|}
\hline \multirow{2}{*}{$\begin{array}{c}\text { Professors' } \\
\text { characteristics }\end{array}$} & \multicolumn{5}{|c|}{ Academic position } & \multirow[t]{2}{*}{ Total } \\
\hline & $\begin{array}{l}\text { Assistant } \\
\text { professor }\end{array}$ & $\begin{array}{l}\text { Associate } \\
\text { professor }\end{array}$ & Professor & Researcher & $\begin{array}{l}\text { Teaching } \\
\text { assistant }\end{array}$ & \\
\hline \multicolumn{7}{|c|}{ Years of experience: } \\
\hline $1-10$ & 16 & 5 & 2 & 3 & 7 & 33 \\
\hline $11-20$ & 5 & 5 & 1 & 2 & 0 & 13 \\
\hline $21-30$ & 1 & 1 & 8 & 0 & 0 & 10 \\
\hline $31-40$ & 0 & 0 & 1 & 0 & 0 & 1 \\
\hline $41-50$ & 0 & 0 & 1 & 0 & 0 & 1 \\
\hline More than 50 & 0 & 0 & 1 & 0 & 0 & 1 \\
\hline \multicolumn{7}{|c|}{\begin{tabular}{|l} 
Usage of the learning management systems (LMSs) in classes: \\
\end{tabular}} \\
\hline No & 10 & 4 & 7 & 1 & 4 & 26 \\
\hline Yes & 12 & 7 & 7 & 4 & 3 & 33 \\
\hline \multicolumn{7}{|c|}{\begin{tabular}{|l|} 
Usage of the social networks and/or e-communities to interact with students: \\
\end{tabular}} \\
\hline No & 14 & 5 & 10 & 3 & 1 & 33 \\
\hline Yes & 8 & 6 & 4 & 2 & 6 & 26 \\
\hline TOTAL & 22 & 11 & 14 & 5 & 7 & 59 \\
\hline
\end{tabular}

Among the students who participated in the online survey, $82.1 \%$ are active in social networks, especially on Facebook, but also on LinkedIn, Google+, Twitter or others, while $73.4 \%$ are active in an online community/platform (e.g. Stackoverflow, online.ase.ro, Girls Who Code, Udemy, Coursera and so on). Only $24.8 \%$ of them use a Learning Management System (LMS) within their classes. Only 39.4\% of students who participated in the online survey are present on social networks to interact both with their teachers and their colleagues; most students are friends with their teachers on Facebook (87.6\%) and on LinkedIn (49.6\%) and they admit that on those social networks they put questions, chat, answer questions, make announcements or just screen their teachers/colleagues - friends. Some students (37.8\%) acknowledge the usefulness of professional social networks in finding a job, while only $17.1 \%$ are really sure that they are not useful (the rest of our respondents don't know). Most of our respondents will use or they might use social networks in the future for keeping in touch with their teachers and school colleagues, while $72.1 \%$ of the interrogated students said that social network play a role in 
lifelong learning activities. Many graduates consider that learning can take place in social networks and admit that they are regular users of social networks, facts which prove that, nowadays, a social platform can support lifelong learning.

Almost $56 \%$ of the IT professors who participated in the online survey admitted that they use a LMS for their classes and $57.6 \%$ of them said they would change their LMS, if suitable. The same number of professors admitted they use the assessment features available in their LMS. In the same time, $44.1 \%$ acknowledged that they use a social network to keep in touch with their students, while the rest don't have students as friends on their social accounts. Among the most common activities professors do on those social networks, with regard to interacting with their students are: making announcements (88.5\% of our respondents), answer questions $(57.7 \%)$ and friendly chat (30.8\%). Most of them (76.9\%) won't put grades based on students' activities on social networks. Only $19.2 \%$ of them said they noticed that students who are active on social networks/e-communities obtain better results at school and a job, $3.8 \%$ said the students who are active on social networks have poor marks, while $76.9 \%$ didn't notice any correlation between social network use and students' grades/employability.

The analysis of the dependencies of the variables by using the Fisher test revealed the following results (Bodea et al, 2016):

- There is a difference between girls and boys in relation with the social network presence.

- There is a correlation between the usage of social networks and individuals' opinion that social networks can improve learning $\left(\mathrm{p}\right.$-value $\left.=2.385^{*} \mathrm{e}^{-8}\right)$.

- There is a correlation between the level of education and the usage of social networks ( $p$-value $=0.0006335$ ). Interestingly, most educated students do not use social networks. The age factor might be an explanation to this result. PhD students tend to be older and are not as familiar as the younger students with new technologies.

In the framework of START-SoPI project, the SMIS concept has been defined by using the following dimensions:

a) Scope and objective. The scope is the interconnection of social learning and recruiting, with the purpose of increasing graduates' employability. The following objectives regarding the platform functionalities were defined:

- Support for several types of users - learners/students and recruiters/companies, professors and universities/career development services can follow graduates.

- Access of knowledge workers to suitable e-learning communities, taking into account their profiles, through an ontology-based recommendation mechanism

- Development of builds learners' profiles, in a quick and accurate manner, via social network connectors (developed with existent social network APIs)

- Promotion of the collaboration, as the central driver in e-learning, by providing a dedicated forum for each elearning community

- Motivating learners by implementing a gamification principle: awards their exceptional virtual behavior with points given by communities' members

- Assuring high visibility to the most appreciated learners and recommends them to employers who joined the platform

b) Market and stakeholders. Even if primary market considered in the project was Danube Region, SMISs have a much wider market. The main SMIS adopters are the following: students/graduates; career development specialists from universities, professors and human resources specialists from companies. Other users or subgroups might be: young professionals, (senior) professionals, corporate executives, senior programmers, and human resources department representatives.

c) Functionalities and modules. Functionalities and modules were defined for each category of stakeholders. The administrative functions for the platform deployment and maintenance were added.

d) Technical dimensions. Advanced IT technologies were considered, such as: technologies for Computer Adaptive Testing (CAT) and ontologies for recommendation mechanisms. Each user should have the possibility to find virtual communities tailored on one's profile, in which members can learn from each other and increase their professional visibility, thus becoming more employable. The recommendation mechanisms can be based on users' data retrieved from platform activities and social interactions, passing it through ontology in order to classify the users and to obtain relevant information for SMIS. 
The main alternatives for developing and implementing SMISs in the context of START-SoPI project were identified (figure 1). A focus group and two interviews with independent professors who are experts in the field of social learning were organized in order to evaluate these technical alternatives.

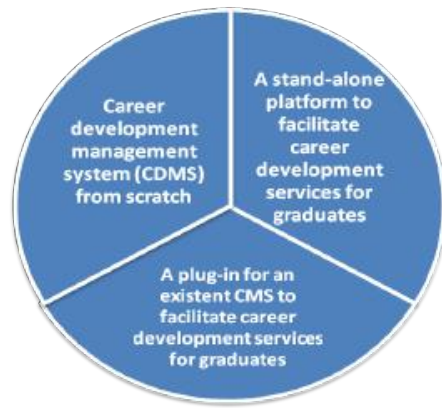

Figure 1. Technical alternatives for the social media information system

a) Content Management System (CMS) to facilitate learning and career development services for graduates. A career development management system (CDMS) is a specialized CMS to facilitate career development services for graduates, with interconnected modules for social learning and recruiting, thus providing support to increase graduates' employability. The solution can be developed from scratch using an open-source web application framework (e.g. Symfony for PHP, Spring for Java, with a MVC architecture). The idea of developing a CMS specialized for career development services is based on the success of other types of CMS, which were created for well-defined purposes: Learning Management Systems - e.g. Moodle, Blackboard, Website Management Systems - e.g. WordPress, Drupal, Scientific Journals Management Systems - e.g. Open Journal Systems and so on.

b) Plug-in for an existent Content Management System (CMS) to facilitate learning and career development services for graduates. The social media information system can be developed based on an existing opensource CMS, by means of a plug-in which adds to that CMS a set of interconnected modules for social learning and recruiting, thus providing support to increase graduates' employability. A plug-in is a software component that adds a specific feature to an existing computer program. The plug-in should be developed for a popular CMS, e.g. Moodle, one of the most used Learning Management System or WordPress, a widely spread CMS for building websites. As many CMS frameworks are open-source, there is the possibility to exploit an existing CMS and to transform it into a specialized one, based on our aim.

c) Stand-alone system providing learning and career development services for graduates. A solution for implementing a social media information system is the development of a stand-alone platform to support learning and career development services, with a set of interconnected modules for social learning and recruiting, thus providing support to increase graduates' employability.

\section{RESULTS}

Based on the collected data, the challenges of implementing SMISs in Danube region were identified. Tables 3, 4 and 5 summarize the study results. 
Table 3. Challenges related to the innovation characteristics

\begin{tabular}{|c|c|c|}
\hline Challenges & $\begin{array}{c}\text { Related innovation } \\
\text { characteristics }\end{array}$ & Comments \\
\hline $\begin{array}{l}\text { Additional time for } \\
\text { monitoring student } \\
\text { activities performed in } \\
\text { social networks/ e- } \\
\text { communities. }\end{array}$ & $\begin{array}{l}\text { Relative advantage } \\
\text { (the innovation is } \\
\text { better than what was } \\
\text { there before) }\end{array}$ & $\begin{array}{l}\text { During interviews, professors expressed their concerns about } \\
\text { the required time for monitoring different student activities in } \\
\text { social networks. In addition, they declared that there isn't a } \\
\text { perceived correlation between the students' behaviour within } \\
\text { social networks/e-communities and the learning results. From } \\
\text { the professors participating in the online survey, } 76.9 \% \\
\text { declared that they won't put grades based on students' } \\
\text { activities on social networks. }\end{array}$ \\
\hline $\begin{array}{l}\text { Lack of professors' } \\
\text { experience in organizing } \\
\text { and monitoring students' } \\
\text { performance in the social } \\
\text { networks/ e-communities. } \\
\text { Also, the lack of interest } \\
\text { in the regular usage of } \\
\text { traditional information } \\
\text { systems (LMSs) }\end{array}$ & $\begin{array}{l}\text { Compatibility (the } \\
\text { innovation fits with } \\
\text { the intended } \\
\text { audience) }\end{array}$ & $\begin{array}{l}\text { Only } 44.1 \% \text { of the professors participating in the online } \\
\text { questionnaire acknowledged that they use a social network to } \\
\text { keep in touch with their students, while the rest don't have } \\
\text { students as friends on their social accounts. } \\
\text { Only } 55.9 \% \text { of the professors participating in the online } \\
\text { survey admitted that they use a LMS for their classes and } \\
57.6 \% \text { of them said they would change their LMS, if suitable } \\
\text { The same number of professors admitted that they use the } \\
\text { assessment features available in their LMS. The functionality } \\
\text { perceived as being most useful for a LMS is sharing } \\
\text { educational content and not communication with the } \\
\text { students. }\end{array}$ \\
\hline $\begin{array}{l}\text { High amount of data } \\
\text { about the students' } \\
\text { activities that has to be } \\
\text { analyzed. }\end{array}$ & $\begin{array}{l}\text { Complexity (the } \\
\text { innovation is easy to } \\
\text { use) }\end{array}$ & $\begin{array}{l}\text { This challenge can be overcome by adding learning analytics } \\
\text { facilities to the SMISs }\end{array}$ \\
\hline $\begin{array}{l}\text { Lack of professors' } \\
\text { interest in connecting with } \\
\text { the students within the } \\
\text { social networks/ e- } \\
\text { communities }\end{array}$ & $\begin{array}{l}\text { Trialability (the } \\
\text { innovation can be } \\
\text { tried before making a } \\
\text { decision to adopt) }\end{array}$ & $\begin{array}{l}\text { There is the possibility to use the existing social networks to } \\
\text { organize some didactic activities, apart from the usual } \\
\text { information system in use in the university. }\end{array}$ \\
\hline $\begin{array}{l}\text { Difficulties in measuring } \\
\text { the learning results of the } \\
\text { activities performed in } \\
\text { social networks/ e- } \\
\text { communities }\end{array}$ & $\begin{array}{l}\text { Observability (the } \\
\text { results of the } \\
\text { innovation are visible } \\
\text { and easily } \\
\text { measurable }\end{array}$ & $\begin{array}{l}\text { Most of the professors participating in online survey and } \\
\text { interviews consider that the activities performed in social } \\
\text { networks have less learning impact. Due to this perception, } \\
\text { the measurement of the learning results achieved in social } \\
\text { networks is even more difficult to be done. }\end{array}$ \\
\hline
\end{tabular}


Table 4. Challenges related to the characteristics of the innovation adopters

\begin{tabular}{|c|c|c|}
\hline Challenges & $\begin{array}{c}\text { Innovation } \\
\text { adopter }\end{array}$ & Comments \\
\hline $\begin{array}{l}\text { The students can be reluctant to } \\
\text { collaborate simultaneous with the } \\
\text { professors and the recruiters in the } \\
\text { same virtual environment. }\end{array}$ & Student & $\begin{array}{l}\text { Only } 3.32 \% \text { of the students participating in the online } \\
\text { survey declared that they are willing to keep the contact } \\
\text { with professors for other activities that those strictly } \\
\text { related to the academic disciplines. }\end{array}$ \\
\hline $\begin{array}{l}\text { The graduate students can be less } \\
\text { interested in regular connections with } \\
\text { professors in social networks / e- } \\
\text { communities. }\end{array}$ & $\begin{array}{l}\text { Graduate } \\
\text { student }\end{array}$ & $\begin{array}{l}\text { Among the students who participated in the online survey, } \\
86.18 \% \text { said they were not interested in getting in touch } \\
\text { regularly with their teachers after graduation. }\end{array}$ \\
\hline $\begin{array}{l}\text { The professors can show a low } \\
\text { interest about the career development } \\
\text { of their students. }\end{array}$ & Professor & $\begin{array}{l}\text { Only } 55.9 \% \text { of the professors participating in the survey } \\
\text { declared that they know the students' employment status, } \\
\text { even if assuring employability is considered as being } \\
\text { important for university. } \\
\text { Only } 1.7 \% \text { of the professors participating in the survey } \\
\text { declared that they know about the carrier development } \\
\text { services offered by university. }\end{array}$ \\
\hline $\begin{array}{l}\text { The specialists in career development } \\
\text { use standard procedures in order to } \\
\text { interact with students, which usually } \\
\text { don't include the activities in social } \\
\text { networks. }\end{array}$ & $\begin{array}{l}\text { Career } \\
\text { developmen } \\
\text { t specialist }\end{array}$ & $\begin{array}{l}\text { During interviews, the career development specialists } \\
\text { admitted that they perform standard procedures in order to } \\
\text { deliver carrier development services, which don't include } \\
\text { regular activities in social networks. }\end{array}$ \\
\hline $\begin{array}{l}\text { The recruitment process does not } \\
\text { directly involve the professors. }\end{array}$ & Recruiter & $\begin{array}{l}\text { During interviews, the companies' representatives showed } \\
\text { a low interest for performing the recruiting activities in } \\
\text { cooperation with professors. Even if the recommendation } \\
\text { letters written by professors are parts of the candidate } \\
\text { dossier, the recruiters declared that they are not interested } \\
\text { to attend activities coordinated by professors in order to } \\
\text { observe the student/candidate performance. }\end{array}$ \\
\hline
\end{tabular}


Table 5. Challenges related to the contextual settings

\begin{tabular}{|l|l|l|}
\hline \multicolumn{1}{|c|}{ Challenges } & \multicolumn{1}{|c|}{ Contextual settings } & \multicolumn{1}{|c|}{ Comments } \\
\hline $\begin{array}{l}\text { The carrier development } \\
\text { services are not well known } \\
\text { by students and professors } \\
\text { and they are not integrated in } \\
\text { the university information } \\
\text { system. }\end{array}$ & $\begin{array}{l}\text { Organization of the } \\
\text { carrier development } \\
\text { centers in universities }\end{array}$ & $\begin{array}{l}\text { Only 1.7\% of the professors and 8.7\% of the students } \\
\text { participating in the surveys declared that they know } \\
\text { about the carrier development services offered by } \\
\text { university. }\end{array}$ \\
\hline $\begin{array}{l}\text { Limited IT infrastructure of } \\
\text { the universities }\end{array}$ & $\begin{array}{l}\text { IT infrastructure of the } \\
\text { universities }\end{array}$ & $\begin{array}{l}\text { During interviews, some of the professors declared that } \\
\text { the information systems they are using have limited } \\
\text { capabilities. 57.6\% of the professors participating in } \\
\text { the online survey declared that they would change their } \\
\text { LMS, if suitable. }\end{array}$ \\
\hline $\begin{array}{l}\text { Lack of standard procedures } \\
\text { in organizing didactical } \\
\text { activities in virtual } \\
\text { environments }\end{array}$ & $\begin{array}{l}\text { Organizational culture } \\
\text { of universities }\end{array}$ & $\begin{array}{l}\text { During interviews, some of the professors declared that } \\
\text { the universities don't have clear procedures how to } \\
\text { organize and perform regular didactical activities in } \\
\text { virtual environments. }\end{array}$ \\
\hline Privacy issues & $\begin{array}{l}\text { Legal constraints } \\
\text { impacting the } \\
\text { education }\end{array}$ & $\begin{array}{l}\text { There is the responsibility of the e-learning platform } \\
\text { owner to protect the privacy of information provided } \\
\text { by students and employees when they are using the e- } \\
\text { learning platform, especially when the activities are } \\
\text { performed with different purposes, (education and } \\
\text { recruitment). In order to overcome these legal } \\
\text { constraints, some information disclosure agreements } \\
\text { with clauses for specific activities can be agreed by the } \\
\text { involved parties. }\end{array}$ \\
\hline
\end{tabular}

\section{SUMMARY}

Based upon the results of our study undertook for the Danube region of Europe, we can conclude that significant challenges exist in adopting and implementing SMISs in universities in specific regions. These challenges are mainly related to the perceptions and motivations of different stakeholders and to the organizational culture of the universities. The technical challenges, in developing and deploying innovative learning platforms are less relevant. The Roger's model allows us to identify three categories of challenges for adopting SMISs, in relation with the SMISs' characteristics, the stakeholders' characteristics and the contextual settings.

The main challenges related to the SMIS characteristics are the following: the additional time for monitoring student activities performed in social networks/ e-communities, the lack of expertise of professors in organizing and monitoring students in the social networks/e-communities and the lack of interest in regular usage of traditional information systems (LMSs), the high amount of data about the students' activities that has to be analyzed by the professors and recruiters, and difficulties in measuring the learning results achieved by performing different activities in social networks/ e-communities.

The following difficulties which are related to the characteristics of stakeholders, as individuals were identified: the students can be reluctant to collaborate simultaneous with the professors and the recruiters in the same virtual environment, the graduate students can be less interested in regular connections with professors in social networks / e-communities, the professors can show a low interest about the career development of their students, the specialists 
in career development use standard procedures, which usually don't include the activities in social networks, and the recruitment process does not directly involve the professors.

Concerning the contextual settings, the following challenges in adopting SMISs were identified: the lack of visibility of the carrier development services, the limited IT infrastructure of the universities, the lack of standard procedures in organizing didactical activities in virtual environments and the privacy issues.

\section{ACKNOWLEDGEMENTS}

The work has received funding from the grant agreement No. 16_PA07-C2, START-SoPI, "Feasibility Study on Implementing a Pan-European Social Platform to Support Lifelong Learning and Employability". START-SoPI is part financed by START - Danube Region Project Fund, an initiative for the Danube Region Strategy. START is financed by the European Union and the City of Vienna.

\section{REFERENCES}

Bodea, C.N., Dascalu, M.I., Velikic, G. and Stancu, S. (2016). Lifelong Learning and Employability in the Danube Region Countries: Influences and Correlations. Amfiteatru Economic, 18(43), 521-536.

Greenhalgh, T., Robert, G. Macfarlane, F., Bate, P., Kyriakidou, O., Peacock, R. (2005). Storylines of Research in Diffusion of Innovation: A Meta-Narrative Approach to Systematic Review, Social Science and Medicine, $61,417-430$.

House, J. S. (1981). Work Stress and Social Support. Reading, Mass.: Addison-Wesley, 1981.

Kroenke, D.M. (2017). Using MIS, $7^{\text {th }}$ edition, Pearson Education, Inc.

Oldenburg,B., Glanz, K. (2008). Diffusion of innovation, in: Glanz, K., Rimer B.K., Viswanath, K. (eds), Health behavior and health education: Theory, Research, and Practice, $4^{\text {th }}$ edition, John Wiley \& Sons, Inc.

Pappas, C. (2015). How To Use Facebook For eLearning: What eLearning Professionals Should Know”, E-learning Industry, available at: http://elearningindustry.com/using-facebook-for-elearning-ultimate-guide-forelearning-professionals .

Rogers, E. (2003). Diffusion of Innovations, 5th Edition, Simon \& Schuster Inc.

Wejnert, B. (2002). Integrating Models of Diffusion of Innovations: A Conceptual Framework., Annual Review of Sociology, 28, 297-326. 